in vivo $34: 723-728(2020)$

doi:10.21873/invivo.11830

\title{
Uselessness of Serum p53 Antibody for Detecting Colitis-associated Cancer in the Era of Immunosuppressive Therapy
}

\author{
KENICHIRO TORITANI ${ }^{1}$, HIDEAKI KIMURA ${ }^{1}$, REIKO KUNISAKI ${ }^{1}$, JUN WATANABE $^{2}$, \\ CHIKARA KUNISAKI ${ }^{2}$, ATSUSHI ISHIBE ${ }^{3}$, SAWAKO CHIBA ${ }^{4}$, YOSHIAKI INAYAMA $^{4}$ and ITARU ENDO ${ }^{3}$ \\ ${ }^{1}$ Inflammatory Bowel Disease Center, Yokohama City University Medical Center, Yokohama, Japan; \\ ${ }^{2}$ Department of Surgery, Gastroenterological Center, Yokohama City University Medical Center, Yokohama, Japan; \\ ${ }^{3}$ Department of Gastroenterological Surgery, \\ Yokohama City University Graduate School of Medicine, Yokohama, Japan; \\ ${ }^{4}$ Department of Pathology, Yokohama City University Medical Center, Yokohama, Japan
}

\begin{abstract}
Background/Aim: The present study examined the utility of serum p53 antibody $(A b)$ for detecting colitisassociated cancer $(C A C)$ in the era of immunosuppressive therapy. Patients and Methods: Two hundred and fifty patients were analyzed, 219 had no carcinoma or dysplasia (Group non-CAC), and 31 had carcinoma or dysplasia (Group CAC). Serum p53 Abs were detected with an enzyme-linked immunosorbent assay. Immunohistochemical detection was performed in Group CAC. Results: Immunosuppressive therapy was performed in $98.1 \%$ of Group non-CAC and $80.6 \%$ of Group CAC. There were no differences in serum $p 53$ Abs positivity between Groups non-CAC and CAC $(8.7 \%$ vs. $3.2 \%, p=0.30$ ). $p 53$ staining positivity was noted in $90.3 \%$ of Group CAC, and the rate of serum p53 positivity was significantly lower in patients with immunosuppressive therapy than in those without in Group CAC $(0.0 \%$ vs. $16.7 \%$, $p=0.04)$. Conclusion: The utility of serum $p 53$ Ab for detecting CAC is dubious in the era of immunosuppressive therapy.
\end{abstract}

Mutations in the p53 tumor suppressor gene are the most frequently reported somatic gene alterations in human cancer $(1,2)$. In the ulcerative colitis (UC)-associated dysplasiacarcinoma sequence, p53 gene mutations are early events

This article is freely accessible online.

Correspondence to: Hideaki Kimura, Inflammatory Bowel Disease Center, Yokohama City University Medical Center, 4-57, Urafunecho, Minami-ku, Yokohama, 232-0024, Japan. Tel: + 81452615656 , Fax: + 81 452615656, e-mail: hkim@ yokohama-cu.ac.jp

Key Words: Ulcerative colitis, colorectal cancer, p53, serum anti-p53 antibodies, immunosuppressive therapy. compared to adenomas related to the typical adenomacarcinoma sequence (3). Mutations in the p53 gene are observed in $50 \%-85 \%$ of colonic tissue specimens of UC with dysplasia or colorectal cancer (4). These mutations result in the accumulation of the p53 protein, which causes p53 overexpression in tissue. There have been many reports of p53 overexpression in cases of ulcerative colitisassociated colorectal cancer (CAC) (5).

Apart from the detection of p53 gene mutations and p53 overexpression associated with CAC, in the 1990's it was reported that serum anti-p53 antibodies are detected as serum IgG antibodies that are present due to an antigen-antibody reaction to $\mathrm{p} 53$ protein. The usefulness of measuring serum anti-p53 Antibodies (Abs) in various malignant tumors has been suggested (6-9). Compared to conventional tumor markers, anti-p53 Abs is useful for detecting early colorectal cancer (10-12). Yoshizawa et al. reported the usefulness of measuring serum anti-p53 Abs in CAC in 2007 (13), which constituted this assessment eligible for health insurance coverage in Japan during that same year.

Interestingly, since the spread of immunosuppressive therapy for UC treatment in the 2010s, we have experienced a low prevalence of anti-p53 Abs in UC patients with CAC. To our knowledge, no data are available in the literature concerning the usefulness of serum p53 Abs for CAC since immunosuppressive therapy became common for UC treatment. The present study therefore explored whether serum p53 Abs are useful for detecting CAC in the era of immunosuppressive therapy.

\section{Patients and Methods}

Study population. From April 2008 to March 2019, 320 consecutive patients who underwent surgical resection for UC were collected 
from the Yokohama City University Medical Center in Japan. The exclusion criterion was no data on serum anti-p53 Abs before the operation. A total of 250 patients were analyzed in this study. We divided the patients into two groups: i) group non-CAC included patients who underwent surgery for severe or intractable colitis and had not been diagnosed with carcinoma or dysplasia histologically by a biopsy or surgical specimen, and ii) group CAC included patients who had been diagnosed with carcinoma or dysplasia. Of these 250 UC patients, 219 (87.6\%) were in Group non-CAC, and $31(12.4 \%)$ were in group CAC (Figure 1). The history of other cancers, smoking and family history of colorectal cancer were reviewed. The clinicopathological features of UC, such as age at time of operation, duration of disease, extension of disease and medications, were collected from the medical records.

An enzyme-linked immunosorbent assay (ELISA) for Anti-p53 Abs and conventional tumor makers. An ELISA for the detection of antip53 Abs in serum was carried out with a commercially available ELISA kit (MESACUP anti-p53 test; Medical \& Biological Laboratories, Nagoya, Japan). In brief, serum samples and calibrators were added to each well of a 96-well microtiter plate coated with wild-type human p53 or control protein. Samples were incubated on the plate for $60 \mathrm{~min}\left(20-30^{\circ} \mathrm{C}\right)$. After washing, peroxidase-conjugated anti-human IgG anti-p53 Abs were added, followed by further incubation for another $60 \mathrm{~min}\left(20-30^{\circ} \mathrm{C}\right)$. After washing again, the substrate was added, and the plate was incubated again for $30 \mathrm{~min}\left(20-30^{\circ} \mathrm{C}\right)$. A stop solution was then added to each well to stabilize the color development. The value in each sample was determined by comparing the optical density of the sample to that of the anti-p53 standard. The cut-off value was $1.3 \mathrm{U} / \mathrm{ml}$, according to a previous colorectal cancer study $(11,14)$. The carcinoembryonic antigen (CEA) levels were measured using a CEA-2 enzyme immune assay (EIA) kit (Elecsys CEAII; Roche Diagnostics K.K., Tokyo, Japan), following the manufacturer's instructions with a cut-off value of $5.0 \mathrm{ng} / \mathrm{ml}$. The cancer antigen 19-9 (CA19-9) levels were measured using a CA19-9 EIA kit (Elecsys CA19-9; Roche Diagnostics K.K.) with a cut-off value of $37 \mathrm{U} / \mathrm{ml}$.

Immunohistochemistry. For patients with dysplasia or CRC by colonoscopy, we also evaluated the p53 status using immunohistochemistry on biopsied or surgical specimens. In brief, paraffin-embedded tissue samples were cut in serial sections of 3-4 $\mu \mathrm{m}$ thickness, placed on coated slides and deparaffinized through a series of xylene and ethanol baths. The slides were then incubated with anti-p53 primary antibodies (DO-7; DAKO, Glostrup, Denmark), followed by biotin-conjugated goat antibody against mouse as a secondary antibody (E0433; DAKO). The following steps were performed using a standard $\mathrm{ABC}$ method (Elite $\mathrm{ABC}$ kit, Vectastain; Vector Laboratories, Burlingame, CA, USA): 3,3Diaminobenzidine was used as substrate for the peroxidase enzyme reaction (Vectastain; Vector Laboratories), and all slides were counterstained with hematoxylin and observed under a microscope (CH40; Olympus, Tokyo, Japan).

Immunosuppressive therapy. In this study, we defined immunosuppressive therapy as one offered to patient with a medical history of i) prednisolone administration exceeding $20 \mathrm{mg}$ per day for the equivalent of 2 weeks or more, ii) immunosuppressant drugs (including cyclosporine and tacrolimus), iii) immunomodulator

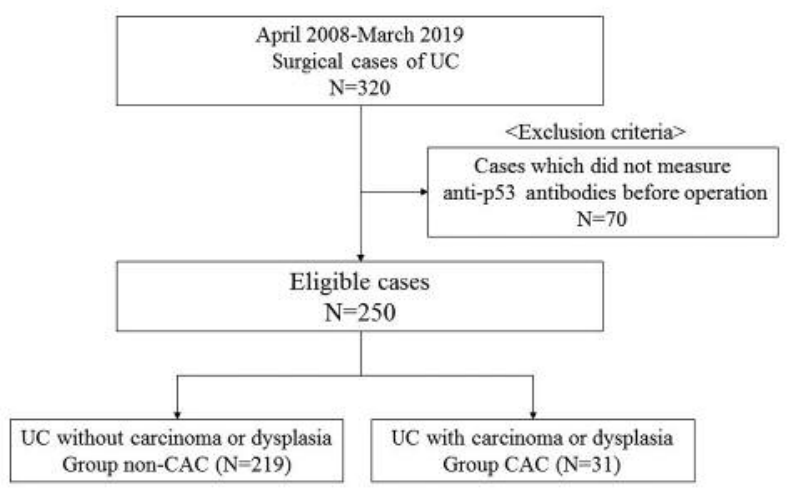

UC: Ulcerative colitis.

Figure 1. Outline of patient selection.

drugs (including 6-mercaptopurine, azathioprine and methotrexate) or iv) biologic therapies (including infliximab and adalimumab) for $\mathrm{UC}$ treatment. According to a previous report, these therapies induce an immunocompromised state in inflammatory bowel disease patients (15).

Statistical analyses. Differences between categorical variables were tested using Pearson's chi-squared test, and differences between continuous variables were tested using the Mann-Whitney $U$-test. Statistical analyses were performed using the SPSS statistical software program, version 22.0 (SPSS Inc., Chicago, IL, USA). All tests were 2 -sided, and $p$-Values less than 0.05 were considered statistically significant.

\section{Results}

Serum anti-p53 Abs and the clinicopathological features of the study population. The demographic and biochemical characteristics of the subjects in all studied groups are shown in Table I. There were no significant differences in the positivity of serum anti-p53 Abs between Group non-CAC and Group CAC ( $8.7 \%$ vs. $3.2 \%, p=0.30)$. The age at the time of operation in Group non-CAC was lower compared to that of Group CAC (40 years $v s .50$ years, $p=0.02$ ). The duration of the disease differed significantly between Group non-CAC and Group CAC ( 6 years vs. 17 years, $p=0.01$ ), and patients with $>8$ years since the UC onset were less frequent in Group non-CAC compared to Group CAC $(25.1 \%$ vs. $87.1 \%$, $p<0.01)$. Immunosuppressive therapy was performed in $98.1 \%$ of Group non-CAC and $80.6 \%$ of Group CAC.

There were no significant differences between the groups in the gender, age at UC onset, disease extent, history of other cancer, smoking, family history of CRC, serum CEA or serum CA19-9.

Serum anti-p53 Abs and tissue p53 overexpression in Group $C A C$. The serum anti-p53 Abs and tissue p53 overexpression 
Table I. Characteristics of the study population.

\begin{tabular}{|c|c|c|c|}
\hline Variables & $\begin{array}{c}\text { Group non-CAC } \\
\qquad N=219\end{array}$ & $\begin{array}{c}\text { Group CAC } \\
\mathrm{N}=31\end{array}$ & $p$-Value \\
\hline \multicolumn{4}{|l|}{ Gender, n (\%) } \\
\hline Male & $125(57.1)$ & $23(74.2)$ & 0.07 \\
\hline Female & $94(43.9)$ & $8(25.8)$ & \\
\hline Age at operation (years), mean \pm SD & $40 \pm 17.7$ & $50 \pm 16.6$ & 0.02 \\
\hline Duration of disease (years), mean \pm SD & $6 \pm 6.5$ & $17 \pm 9.2$ & 0.01 \\
\hline$>8$ years, $\mathrm{n}(\%)$ & $55(25.1)$ & $27(87.1)$ & $<0.01$ \\
\hline Age at UC onset (years), mean \pm SD & $33.6 \pm 17.2$ & $32.4 \pm 15.6$ & 0.26 \\
\hline \multicolumn{4}{|l|}{ Disease extent, $\mathrm{n}(\%)$} \\
\hline Extensive colitis & $208(95.0)$ & $29(93.5)$ & 0.74 \\
\hline Left-sided colitis & $11(5.0)$ & $2(6.5)$ & \\
\hline Proctitis & 0 & 0 & \\
\hline History of other cancer, $\mathrm{n}(\%)$ & $5(2.3)$ & 0 & 0.40 \\
\hline Smoking, n (\%) & $33(15.1)$ & $8(25.8)$ & 0.13 \\
\hline Immunosuppressive therapy, n (\%) & $215(98.1)$ & $25(80.6)$ & $<0.01$ \\
\hline Family history of CRC, n (\%) & $11(5.0)$ & $4(12.9)$ & 0.08 \\
\hline Serum anti-p53 antibodies positive, $\mathrm{n}(\%)$ & $19(8.7)$ & $1(3.2)$ & 0.30 \\
\hline Serum CEA (ng/ml), positive, $\mathrm{n}(\%)$ & $18(8.2)$ & $2(6.5)$ & 0.73 \\
\hline Serum CA 19-9 (U/ml, positive, n (\%) & $10(4.5)$ & $2(6.5)$ & 0.65 \\
\hline
\end{tabular}

Group non-CAC: Ulcerative colitis without carcinoma or dysplasia; Group CAC: ulcerative colitis with carcinoma or dysplasia; UC: ulcerative colitis; CRC: colorectal cancer; CEA: carcinoembryonic antigen; CA19-9: carbohydrate antigen 19-9.

in Group CAC are shown in Table II. p53 overexpression in tumor tissue was noted in $90.3 \%$ of Group CAC. Both serum anti-p53 Abs and tissue p53 overexpression were positive only in Patient 3, who was diagnosed with CRC and did not undergo immunosuppressive therapy.

Association between anti-p53 Abs and immunosuppressive therapy. The association between anti-p53 Abs and immunosuppressive therapy is shown in Table III. The rate of positivity for anti-p53 Abs was significantly lower in those who underwent immunosuppressive therapy before their operation compared to those who did not undergo immunosuppressive therapy before their operation in Group CAC $(0.0 \%$ vs. $16.7 \%, p=0.04)$.

\section{Discussion}

We analyzed a total 250 UC patients, including 31 patients with carcinoma or dysplasia. The rate of positivity for serum anti-p53 Abs was only $3.2 \%$ in patients with carcinoma or dysplasia and $8.7 \%$ in those without carcinoma or dysplasia. Our study clarified that serum anti-p53 Abs measurement does not aid in the detection of CAC.

$\mathrm{Lu}$ et al. have shown in their meta-analysis that p53 expression was positive in cases of UC associated with carcinoma and dysplasia (5). The frequency of anti-p53 Abs in patients with tumors is strictly correlated with the frequency of p53 mutations (16). There is generally a good correlation between the presence of anti-p53 Abs and the p53 accumulation and/or mutations in a tumor (17). Previous studies have reported that the presence of anti-p53 Abs in UC with carcinoma or dysplasia was significantly more frequent than in UC without carcinoma or dysplasia $(40.0 \%$ $61.5 \%$ vs. $12.8 \%-13.3 \%)(17,18)$. Therefore, measuring antip53 Abs may aid in the early detection of carcinoma or dysplasia in UC patients.

In the present study, the p53 expression was positive in $90.3 \%$ of UC patients with carcinoma or dysplasia, however, anti-p53 Abs was positive in only $3.2 \%$ of UC patients with carcinoma or dysplasia. The rate of p53 overexpression was, thus, high in tumors despite a low prevalence of serum antip53 Abs in UC with carcinoma or dysplasia. Some reports have demonstrated the high rate of p53 mutations in tumors and the low prevalence of anti-p53 Abs $(19,20)$. One factor associated with this observation is the immunological malformation that may influence the production of anti-p53 Abs in patients with p53 mutant tumors (20). Over the past decade, UC patients have tended to develop immunological malformation because immunosuppressive therapy has been used more frequently and earlier during the course of the disease to treat UC (21). In addition to steroid therapy, immunomodulatory and immunosuppressant drugs and biologic therapy [specifically anti-tumor necrosis factor (anti-TNF)] have been key to the treatment of UC, as the efficacy of immunomodulatory drugs for UC maintenance therapy is reported since 2012 (22), and that of biological therapies since 2011 (23). 
Table II. Clinicopathological characteristics of ulcerative colitis with cancer or dysplasia.

\begin{tabular}{|c|c|c|c|c|c|c|c|c|c|c|}
\hline Patients & Gender & Age & Duration & $\begin{array}{c}\text { Immunosuppressive } \\
\text { therapy }\end{array}$ & Histology & Stage & $\begin{array}{c}\mathrm{p} 53 \\
\text { overexpression }\end{array}$ & $\begin{array}{l}\text { Anit-p53 } \\
\text { antibodies }\end{array}$ & $\begin{array}{c}\text { Serum } \\
\text { CEA }\end{array}$ & $\begin{array}{l}\text { Serum } \\
\text { CA19-9 }\end{array}$ \\
\hline 1 & $\mathrm{~F}$ & 83 & 43 & - & tub1 & III & + & - & + & - \\
\hline 2 & $\mathrm{~F}$ & 29 & 13 & - & tub1 & III & + & - & - & + \\
\hline 3 & M & 37 & 11 & - & tub1 & II & + & + & - & - \\
\hline 4 & M & 72 & 15 & - & tub1 & II & + & - & - & - \\
\hline 5 & M & 19 & 4 & - & tub1 & I & + & - & - & - \\
\hline 6 & M & 60 & 28 & - & HGD & n.a. & + & - & - & - \\
\hline 7 & M & 39 & 18 & PSL & tub2 & IV & + & - & + & - \\
\hline 8 & M & 82 & 4 & IM, PSL & tub2 & III & - & - & - & - \\
\hline 9 & M & 65 & 25 & IM, PSL & tub2 & III & - & - & - & - \\
\hline 10 & M & 46 & 21 & IM, PSL & tub2 & II & + & - & - & - \\
\hline 11 & M & 51 & 16 & IM, PSL & muc & II & + & - & - & - \\
\hline 12 & M & 50 & 24 & Bio, PSL & tub1 & I & + & - & - & - \\
\hline 13 & M & 42 & 11 & Bio & tub1 & I & + & - & - & - \\
\hline 14 & M & 35 & 16 & IM & tub1 & I & + & - & - & + \\
\hline 15 & M & 38 & 21 & IM & tub1 & I & + & - & - & - \\
\hline 16 & $\mathrm{~F}$ & 35 & 16 & PSL & tub2 & I & + & - & - & - \\
\hline 17 & $\mathrm{~F}$ & 55 & 15 & PSL & tub1 & I & + & - & - & - \\
\hline 18 & M & 48 & 19 & PSL & tub1 & I & + & - & - & - \\
\hline 19 & M & 45 & 16 & PSL & tub1 & I & + & - & - & - \\
\hline 20 & M & 41 & 24 & Bio, PSL & tub1 & 0 & + & - & - & - \\
\hline 21 & $\mathrm{~F}$ & 52 & 12 & PSL & tub2 & 0 & + & _- & - & - \\
\hline 22 & $\mathrm{~F}$ & 38 & 8 & IM, Bio, IS, PSL & tub1 & 0 & $\begin{array}{l}\top \\
-\end{array}$ & - & - & - \\
\hline 23 & M & 40 & 15 & Bio, PSL & HGD & n.a. & + & _- & _ & _- \\
\hline 24 & M & 75 & 18 & IM, Bio, IS, PSL & HGD & n.a. & + & - & - & - \\
\hline 25 & M & 63 & 37 & PSL & HGD & n.a. & - & - & - & - \\
\hline 26 & M & 72 & 26 & PSL & HGD & n.a. & + & - & - & - \\
\hline 27 & M & 70 & 4 & PSL & HGD & n.a. & + & - & - & - \\
\hline 28 & M & 51 & 31 & PSL & LGD & n.a. & + & - & - & - \\
\hline 29 & $\mathrm{~F}$ & 35 & 11 & IM, PSL & LGD & n.a. & + & - & - & - \\
\hline 30 & M & 62 & 14 & IM, Bio, IS, PSL & LGD & n.a. & + & - & - & - \\
\hline 31 & $\mathrm{~F}$ & 27 & 6 & PSL & LGD & n.a. & + & - & - & - \\
\hline
\end{tabular}

M: Male; F: female; PSL: prednisolone; IM: immunomodulator drugs; Bio: biological therapies; IS: immunosuppressant drugs; tub2: moderately differentiated tubular adenocarcinoma; tub1: well differentiated tubular adenocarcinoma; HGD: high grade dysplasia; LGD: low grade dysplasia; n.a.: not applicable; CEA: carcinoembryonic antigen; CA19-9: carbohydrate antigen 19-9.

Some reports have suggested that immunosuppressive therapy might induce a low antibody response rate to various vaccines, because immunosuppressive therapy during multiple steps of the inflammation cytokine cascade $(21,24-26)$. We considered that the low prevalence of anti-p53 Abs might be caused by a low antibody response to 553 protein induced by the immunosuppressive therapy in UC patients, as the positivity for anti-p53 Abs was significantly lower in UC patients with cancer or dysplasia with immunosuppressive therapy compared to those without.

Several limitations associated with the present study warrant mention. First, some cases did not have anti-p53 Abs measured before the operation, particularly emergency surgery cases. We therefore excluded these cases from this study. Second, this was a small-scale single-institutional study, wholly comprising Japanese patients. A large-scale multi-institutional study is, thus, needed.
Table III. Association between anti-p53 antibodies and immunosuppressive therapy.

\begin{tabular}{lccc}
\hline $\begin{array}{l}\text { Group CAC } \\
\mathrm{N}=31\end{array}$ & $\begin{array}{r}\text { Serum anti-p53 } \\
\text { antibodies (+) }\end{array}$ & $\begin{array}{c}\text { Serum anti-p53 } \\
\text { antibodies (-) }\end{array}$ & $p$-Value \\
\hline $\begin{array}{l}\text { Immunosuppressive } \\
\text { therapy (-) N=6 }\end{array}$ & $1(16.7 \%)$ & $5(83.3 \%)$ & 0.04 \\
$\begin{array}{l}\text { Immunosuppressive } \\
\text { therapy (+) } \mathrm{N}=25\end{array}$ & $0(0.0 \%)$ & $25(100.0 \%)$ & \\
\hline
\end{tabular}

Group CAC: Ulcerative colitis with carcinoma or dysplasia.

In conclusion, there was no marked difference in the serum anti-p53 Abs between UC cases with carcinoma or dysplasia and those without. Serum p53 Abs were not associated with p53 immunoreactivity in CAC patients with immune-suppressive 
therapy. The usefulness of serum p53 Abs in detecting CAC is dubious in the era of immunosuppressive therapy.

\section{Conflicts of Interest}

The Authors declare that they have no conflicts of interest for this work.

\section{Authors' Contributions}

KT and HK contributed to the study design. All Authors contributed to the data collection, data analysis, and interpretation. KT and HK contributed to the statistical analyses. All Authors contributed to the writing or review of the report and approved the final version.

\section{Acknowledgements}

None.

\section{References}

1 Lawrence MS, Stojanov P, Mermel CH, Robinson JT, Garraway LA, Golub TR, Meyerson M, Gabriel SB, Lander ES and Getz G: Discovery and saturation analysis of cancer genes across 21 tumour types. Nature 505(7484): 495-501, 2014. PMID: 24390350. DOI: 10.1038/nature 12912

2 Sabapathy K and Lane DP: Therapeutic targeting of p53: all mutants are equal, but some mutants are more equal than others. Nat Rev Clin Oncol 15(1): 13-30, 2018. PMID: 28948977. DOI: 10.1038/nrclinonc.2017.151

3 Scarpa M, Castagliuolo I, Castoro C, Pozza A, Scarpa M, Kotsafti A and Angriman I: Inflammatory colonic carcinogenesis: a review on pathogenesis and immunosurveillance mechanisms in ulcerative colitis. World J Gastroenterol 20(22): 6774-6785, 2014. PMID: 24944468. DOI: 10.3748/wjg.v20.i22.6774

4 Foersch S and Neurath MF: Colitis-associated neoplasia: Molecular basis and clinical translation. Cell Mol Life Sci 71(18): 3523-3535, 2014. PMID: 24830703. DOI: 10.1007/ s00018-014-1636-x

5 Lu X, Yu Y and Tan S: p53 expression in patients with ulcerative colitis - associated with dysplasia and carcinoma: a systematic meta-analysis. BMC Gastroenterol 17(1): 111, 2017. PMID: 29070013. DOI: 10.1186/s12876-017-0665-y

6 Shimada H, Ochiai T, Nomura F and Japan p53 Antibody Research Group: Titration of serum p53 antibodies in 1,085 patients with various types of malignant tumors: a multiinstitutional analysis by the Japan p53 Antibody Research Group. Cancer 97(3): 682-689, 2003. PMID: 12548611. DOI: $10.1002 /$ cncr.11092

7 Kunizaki M, Hamasaki K, Wakata K, Tobinaga S, Sumida Y, Hidaka S, Yasutake T, Miyazaki T, Matsumoto K, Yamasaki T, Sawai T, Hamamoto R, Nanashima A and Nagayasu T: Clinical value of serum p53 antibody in the diagnosis and prognosis of esophageal squamous cell carcinoma. Anticancer Res 38(3): 1807-1813, 2018. PMID: 29491120. DOI: 10.21873/anticanres. 12419

8 Kunizaki M, Fukuda A, Wakata K, Tominaga T, Nonaka T, Miyazaki T, Matsumoto K, Sumida Y, Hidaka S, Yasutake T,
Sawai T, Hamamoto R, Nanashima A and Nagayasu T: Clinical significance of serum p53 antibody in the early detection and poor prognosis of gastric cancer. Anticancer Res 37(4): 19791984, 2017. PMID: 28373470. DOI: 10.21873/anticanres.11540

9 Nozoe T, Nozoe E, Kono M, Ohga T and Ezaki T: Further evidence to demonstrate the significance of serum appearance of anti-p53 antibody as a marker for progressive potential in invasive ductal carcinoma of the breast. J Med Invest 64(3.4): 241-244, 2017. PMID: 28954989. DOI: 10.2152/jmi.64.241

10 Kunizaki M, Sawai T, Takeshita H, Tominaga T, Hidaka S, To K, Miyazaki T, Hamamoto R, Nanashima A and Nagayasu T: Clinical value of serum p53 antibody in the diagnosis and prognosis of colorectal cancer. Anticancer Res 36(8): 4171-4175, 2016. PMID: 27466527.

11 Kumamoto K, Ishida H, Kuwabara K, Amano K, Chika N, Okada N, Ohsawa T, Kumagai Y and Ishibashi K: Clinical significance of serum anti-p53 antibody expression following curative surgery for colorectal cancer. Mol Clin Oncol 7(4): 595600, 2017. PMID: 28855992. DOI: $10.3892 /$ mco.2017.1368

12 Liu S, Tan Q, Song Y, Shi Y and Han X: Anti-p53 autoantibody in blood as a diagnostic biomarker for colorectal cancer: A metaanalysis. Scand J Immunol e12829, 2019. PMID: 31536647. DOI: $10.1111 / \mathrm{sji} .12829$

13 Yoshizawa S, Matsuoka K, Inoue N, Takaishi H, Ogata H, Iwao Y, Mukai M, Fujita T, Kawakami Y and Hibi T: Clinical significance of serum p53 antibodies in patients with ulcerative colitis and its carcinogenesis. Inflamm Bowel Dis 13(7): 865873, 2007. PMID: 17285596. DOI: 10.1002/ibd.20112

14 Ota M, Fujii S, Ichikawa Y, Suwa H, Tatsumi K, Watanabe K, Yamagishi S, Tanaka K, Akiyama H and Endo I: Clinical significance of measuring serum p53antibodies in colorectal cancer patients. Jpn J Gastroenterol Surg 43(9): 996-1001, 2010. DOI: $10.5833 /$ jjgs .43 .996

15 Chaudrey K, Salvaggio M, Ahmed A, Mahmood S and Ali T: Updates in vaccination: recommendations for adult inflammatory bowel disease patients. World J Gastroenterol 21(11): 31843196, 2015. PMID: 25805924. DOI: 10.3748/wjg.v21.i11.3184

16 Soussi T: The humoral response to the tumor-suppressor geneproduct p53 in human cancer: implications for diagnosis and therapy. Immunol Today 17(8): 354-356, 1996. PMID: 8783493. DOI: $10.1016 / 0167-5699(96) 30019-4$

17 Hamouda HE, Zakaria SS, Ismail SA, Khedr MA and Mayah WW: p53 antibodies, metallothioneins, and oxidative stress markers in chronic ulcerative colitis with dysplasia. World J Gastroenterol 17(19): 2417-2423, 2011. PMID: 21633642. DOI: 10.3748/wjg.v17.i19.2417

18 Yamaguchi T, Takii Y and Maruyama S: Usefulness of serum p53 antibody measurement in colorectal cancer: an examination of 1384 primary colorectal cancer patients. Surg Today 44(8): 1529-1535, 2007. PMID: 23975589. DOI: 10.1007/s00595-0130703-5

19 Moch C, Moysan A, Lubin R, Salmoniere P, Soufir N, Galisson F, Vilmer C, Venutolo E, Le Pelletier F, Janin A and BassetSeguin N: Divergence between the high rate of p53 mutations in skin carcinomas and the low prevalence of anti-p53 antibodies. Br J Cancer 85(12): 1883-1886, 2001. PMID: 11747330. DOI: 10.1054/bjoc.2001.2185

20 Umeda J, Itoi T, Sofuni A, Itokawa F, Kurihara T, Tsuchiya T Ishii K, Tsuji S, Ikeuchi N, Tanaka R, Tonozuka R, Honjo M, Mukai S, Nagao T, Oshiro H and Moriyasu F: Serum p53 
antibody is not associated with p53 immunoreactivity in patients with pancreatobiliary cancers. J Oncol, 2013. PMID: 24454372. DOI: $10.1155 / 2013 / 170625$

21 Pratt PK Jr, David N, Weber HC, Little FF, Kourkoumpetis T, Patts GJ, Weinberg J and Farraye FA: Antibody response to hepatitis B virus vaccine is impaired in patients with inflammatory bowel disease on infliximab therapy. Inflamm Bowel Dis 24(2): 380-386, 2018. PMID: 29361083. DOI: 10.1093/ibd/izx001

22 Khan KJ, Dubinsky MC, Ford AC, Ullman TA, Talley NJ and Moayyedi P: Efficacy of immunosuppressive therapy for inflammatory bowel disease: a systematic review and metaanalysis. Am J Gastroenterol 106(4): 630-642, 2011. PMID: 21407186. DOI: $10.1038 /$ ajg. 2011.64

23 Ford AC, Sandborn WJ, Khan KJ, Hanauer SB, Talley NJ and Moayyedi P: Efficacy of biological therapies in inflammatory bowel disease: systematic review and meta-analysis. Am J Gastroenterol 106(4): 644-659, 2011. PMID: 21407183. DOI: 10.1038/ajg.2011.73
24 Haykir Solay A and Eser F: High dose hepatitis B vaccine is not effective in patients using immunomodulatory drugs: a pilot study. Hum Vaccin Immunother 15(5): 1177-1182, 2019. PMID: 30676860. DOI: 10.1080/21645515.2019.1574151

25 Fiorino G, Peyrin-Biroulet L, Naccarato P, Szabo H, Sociale OR, Vetrano S, Fries W, Montanelli A, Repici A, Malesci A and Danese S: Effects of immunosuppression on immune response to pneumococcal vaccine in inflammatory bowel disease: a prospective study. Inflamm Bowel Dis 18(6): 1042-1047, 2012. PMID: 21674732. DOI: 10.1002/ibd.21800

26 Cullen G, Bader C, Korzenik JR and Sands BE: Serological response to the $2009 \mathrm{H} 1 \mathrm{~N} 1$ influenza vaccination in patients with inflammatory bowel disease. Gut 61(3): 385-391, 2012. PMID: 21757451. DOI: 10.1136/gutjnl-2011-300256

Received November 7, 2019

Revised November 16, 2019

Accepted November 26, 2019 